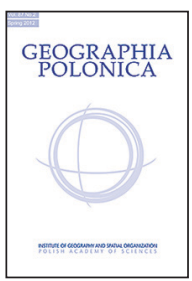

\title{
THE IMPORTANCE AND DIFFUSION OF KNOWLEDGE IN THE AGRICULTURAL SECTOR: THE POLISH EXPERIENCES
}

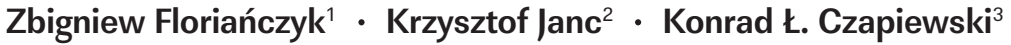

\author{
${ }^{1}$ Institute of Agricultural and Food Economics \\ Świętokrzyska 20, 00-002 Warsaw: Poland \\ e-mail address: florianczyk@ierigz.waw.pl \\ ${ }^{2}$ Institute of Geography and Regional Development \\ University of Wrocław \\ Kuźnicza 49/55, 50-138 Wrocław: Poland \\ e-mail address: krzysztof.janc@uni.wroc.pl \\ ${ }^{3}$ Institute of Geography and Spatial Organization \\ Polish Academy of Sciences \\ Twarda 51/55, 00-818 Warsaw: Poland \\ e-mail address: konrad@twarda.pan.pl
}

\begin{abstract}
The main aim of the work described here was to investigate knowledge transfer to farms, as well as to analyse the levels of knowledge present as this relates to farm performance. Possible inefficiency of knowledge utilisation was investigated at the levels of the individual farm, the gmina (commune - unit of local government administration in Poland) and the region. It emerged from this that the performance of farms was closely related to level of knowledge, with results offering a basis for the elaboration of different models for knowledge transfer in agriculture. Specifically, the three models distinguished in relation to the path of information flow are peer to peer, global information or direct from supplier.
\end{abstract}

\section{Key words}

knowledge transfer $\cdot$ human capital • rural policy • rural areas - rural development • agricultural production • Poland

\section{Introduction}

The range of factors determining the economic performances of farms have changed over time. While natural conditions were critical historically where agriculture production was concerned, the later achievements of agronomy and the management sciences have been such as to ensure that these aspects proved to be of ever-greater importance. Nevertheless, changes of this kind come at a price, since farmers must be familiar with the current state of biological, technical and economic knowledge, which is to say that the manager of a contemporary farm must understand, not only the processes influencing agricultural production directly, but also aspects of the surrounding social and economic environment.
The growth of the non-agricultural functions of rural areas is creating opportunities for the potential of rural areas to be exploited more efficiently. In essence, farmers' incomes are seen to benefit where agriculture production is combined with off-farm activities (Hill \& Cook 1996). Diversification of sources of income on family farms is seen to stand in the way of what would otherwise be a steadily worsening economic situation reflecting fluctuating agricultural prices and terms of trade development unfavourable for farmers.

This implies that a farm's success may be markedly associated with skilful resource reallocation. "Skilful" is a key word here, since the effectiveness of reallocation is found to depend on the degree of innovativeness farmers show as they explore the multifunctionality of rural areas (Swagemakers 2003). This is to say that the 
multifunctional rural development concept is demands more in terms of knowledge than the traditional one focusing on agriculture per se. There will need to be a combining of the knowledge as regards agronomy (allowing a farm operator to recognize and adopt the most promising farm technologies) with the knowledge necessary to run non-agricultural businesses. In this regard, European development strategy emphasizes the roles to be played by knowledge and innovation where economic progress is concerned (European Commission 2010), at the same time recognizing that a reluctance of some parts of our societies to embrace innovation is a major obstacle to development. Overall, the growing role for, and spectrum of, knowledge regarding the agricultural and rural development process is sufficient to justify a reinvestigation of how knowledge affecting the performance of farms as multifunctional rural enterprises.

Specifically, the analysis presented combines microeconomic data on farms with aggregated indicator data for EU regions and Polish gminas with a view to describing spatial aspects to the role level of knowledge plays in agriculture and rural development in the first decade of the 21st century. This is done in order for knowledge transfer to farms to be investigated, as well as knowledge level and relationships with farm performance analysed. Conclusions are arrived at so that these might be used in elaborating different knowledge-transfer models in relation to agriculture effectiveness and the support process where the planning of rural development policies is concerned.

\section{Knowledge in agricultural and rural development concepts}

The beginning of the 20th century brought intensified discussion on knowledge and its place in social and economic progress. The basic question was related to the nature of knowledge, as represented by technology and human skills that were recognized to be external in relation to capital (Clark 1907). Contrary to this early concept of the role of knowledge in progress, Veblen $(1908 a, b)$ argued that knowledge is the most important factor of production, i.e. relevant to the creation and utilisation of material capital. In other words, the value of material capital can be taken to be defined by knowledge of the people who use it. This concept was developed and applied in agriculture by Schultz (1961), who recognized knowledge as an integral part of all-inclusive productive capital. This allowed for accurate valuation of human capital's role in agricultural growth, as this corresponds with other elements to the capital deployed in the name of production. Despite this pioneering work, until the 1980s, technological change in production was recognised as exogenous by the prevailing group of economists (McCormick 2002). This concept was based on the neoclassical model of economic grow proposed by Solow (1956), which integrates technological change as a multiplier where the production function is concerned. Changes in production technology were treated as endogenous to the growth models proposed by Lucas (1988) and Romer (1990, 1994), and in the wake of their work, growth theories came to be complemented by knowledge represented in terms of the level of human capital (Chatterji 1998; Bassanini \& Scarpetta 2002; Lloyd-Ellis \& Roberts 2002; Brunello \& Comi 2004). Prior to that work, knowledge as part of human capital had become a fundamental descriptor of concepts explaining differences in the effectiveness of economies. Human capital as defined by Becker (1962) stressed the importance of investment in personal knowledge via public education, training and information on economic systems. The concept of human capital after de la Fuente and Ciccone (2002) in turn stressed the knowledge and skills accumulated by way of education, training and personal experience that is useful in the production process as well as a stimulant to the further accumulation of knowledge.

Thus knowledge in agriculture, as in all sectors of the economy, can be assumed a key factor stimulating increases in productivity through the better utilisation of resources. In the first half of the 20th century, Walter Wilcox pointed out that "educational work (...) is needed to acquaint farmers with the available information on the productiveness of certain forms of capital in their farming systems" (Wilcox 1943: 63). At that point knowledge became an explanatory variable where agriculture growth was concerned. The next half-century saw developed models for agricultural growth emphasising the role of new technologies and the level of farmers' knowledge, while at the same time pointing out the external origins thereof (Eicher \& Staatz 1998). In fact, among the theoretical models existing for agricultural growth, it is the induced innovation model proposed by Hayami and Ruttan (1985) that has technical change as endogenous.

Contemporary concepts of agriculture development base themselves to a marked degree on advances in technology. In the case of European agriculture, it is the paradigm of multifunctionality (Van Huylenbroeck \& Durand 2003) that dominates, stressing that the successful operation of a farm depends on a multi-disciplinary and trans-disciplinary approach to skills. This is accounted for by a changing in the fields of operation of farms from the agricultural through to the 'rural business'-related, this entailing farmers being 'transformed' into managers. In practice, this denotes - on the one hand - a search for opportunities on the part of farmers, and - on the other - a monitoring of the changing environment in which farms operate, this requiring continuous furthering of the level of knowledge possessed (Czapiewski \& Janc 2008). This points towards an adjustment to the traditional means by which farmers' knowledge expands, which is to say primarily via the stationary educational services. Invoking the aforementioned van Huylenbroeck and Guy Durand development paradigm, we note how adjustment of the educational services available to farmers should both broaden the range of knowledge on offer and provide for more far-reaching specialisation. This kind of complexity to the process of knowledge transfer is what leaves effectiveness rather sensitive to the detection of knowledge-related structures. 
The Lundvall (1996) concept for the creation and transfer of knowledge makes reference to the four major knowledge domains of 'know-what, know-why, know-how and know-who'. While the first two of these are related to the codified knowledge accessible via such common sources as books and classes, the two last link up with the tacit knowledge possessed by individuals thanks to their personal experience with solving problems and their social interactions. Contemporary research stresses how importance it may be for a balance to be set between these codified and tacit sources and aspects of knowledge (Guile 2001). Some go yet further, suggesting that the latter (tacit) aspect be given priority (Gertler 2003; Howells 2002). What is crucial here is the degree to which tacit knowledge can be regarded as territory-related, since the unique characteristics of regions often go hand in hand with specific resources defining their potential as regards the creation and absorption of knowledge (Bathelt et al. 2004; Storper \& Venables 2004). According to Hilpert (2006), such regional knowledge comes from different sources as science, tradition, culture or regional management. The other aspect to knowledge development relates to proximity to potential sources, as defined, not only by reference to physical space, but also in regard to the mobility of human capital, the densities of social networks and the quality of culture (Boschma \& Lambooy 1999). From among a proposed five types of proximity, Boschma (2005) underlines cognitive and organizational knowledge - a type that Lagendijk and Lorentzen (2007) see as of special importance where flow between the centre and the periphery is concerned. The role of common knowledge as a part of the environment necessary for the achievement of personal success is stressed by Florida (2004) and Törnqvist (2004), while other researchers feel that a proper milieu reflecting common knowledge is what stimulates the creativity critical for an innovative economy milieu (Gössling \& Rutten 2007). The structural problem of the new knowledge transfer and its implementation is further complicated in rural areas by agriculture diversity (Floriańczyk et al. 2009). While conventional farms demand highly-specialised technologies, those in transition are rather in need of knowledge relating to non-agricultural opportunities.

In practice, these two types of knowledge essential for modern agriculture and rural development are of interest to development policies. Thus the EU's Common Agricultural Policy offers training programs for farmers, as well as programs that assist directly with the introduction of modern farming technologies (European Commision 2009). However, since a general trend for possibilities for employment in non-agricultural sectors to grow can lead to a withdrawal of human capital from farms that can not provide satisfactory incomes, it may be the case that knowledge intended to stimulate agricultural development actually ends up supporting other sectors of the economy. This phenomenon can be described as a 2-layer inefficiency, wherein the first layer reflects unnecessary public spending on a knowledge increase that is only taken advantage of in part, while the second relates to a failure to ensure that rural areas are provided with non-agricultur- al knowledge more appropriate for a multifunctional type of development.

The complex structures of rural knowledge required offer an indication that modern information and communications technologies (ICT) constitute a proper measure where challenges of knowledge transfer are concerned. The ICT potential as regards knowledge diffusion is of particular interest in agriculture, which is by definition spatially dispersed, with all the relatively unfavourable consequences that can have for both creativity and knowledge transfer. Among other things, ICT can effectively shrink the physical distance separating rural areas from metropolises (knowledge centres)-(Johnson 2001; Malecki 2003). Indeed, it might be stressed that a immanent characteristic of ICT development is its urban origin (Poncet \& Ripert 2007). This implies uneven access to, and uneven utilization of, ICT, between urban and rural areas (Fox \& Porca 2007; Whitacre \& Mills 2007). In extremis, higher costs associated with infrastructural development combine with a situation in which the rural populace is clearly less skilled with the utilization of modern $I C T$, to create an environment for a digitally divided (rural versus urban) society (Grimes 2000; Warren 2007).

This means that uneven chances for development when rural populations are set against urban population can be characterized in relation to relatively poorer access to knowledge and a more limited ability to utilise modern communications technologies. Similarly, agriculture's traditionally strong dependence on local natural and social resources creates natural internal forces for stabilisation. These are a key problem where multi-directional rural development is postulated. The problem of adequate knowledge transfer into European agriculture and rural areas is seen to be more serious in regions with a large number of subsistence farms, as subsistence-type farms prefer informal types of knowledge that relate to succession and own experience. In contrast, modern agriculture is largely founded upon links with formal knowledge based on research achievements (Klepacki 2005). The growing complexity of the knowledge-transfer issue in rural areas can therefore be characterized as a problem of proper transfer and targeting.

\section{Interdependence between knowledge and farm performance - the Polish case}

In most countries, farmers belongs to a socio-economic group with a below-average level of education. As of 2006, over half of all inhabitants of Poland's rural areas working in non-agricultural sectors of the economy had secondary or tertiary education, as compared with only $1 / 4$ of farmers in agriculture as such. Nevertheless, the last few decades have brought a considerable improvement in the farming population's level of education. While in 1960, almost $97 \%$ of the farming population could at best claim to have primary education; by 2007 the comparable figure was just $26 \%$ of those in farming (Fig. 1). The change has thus been a rapid one, which has coincided with Poland's period of systemic transformation. 


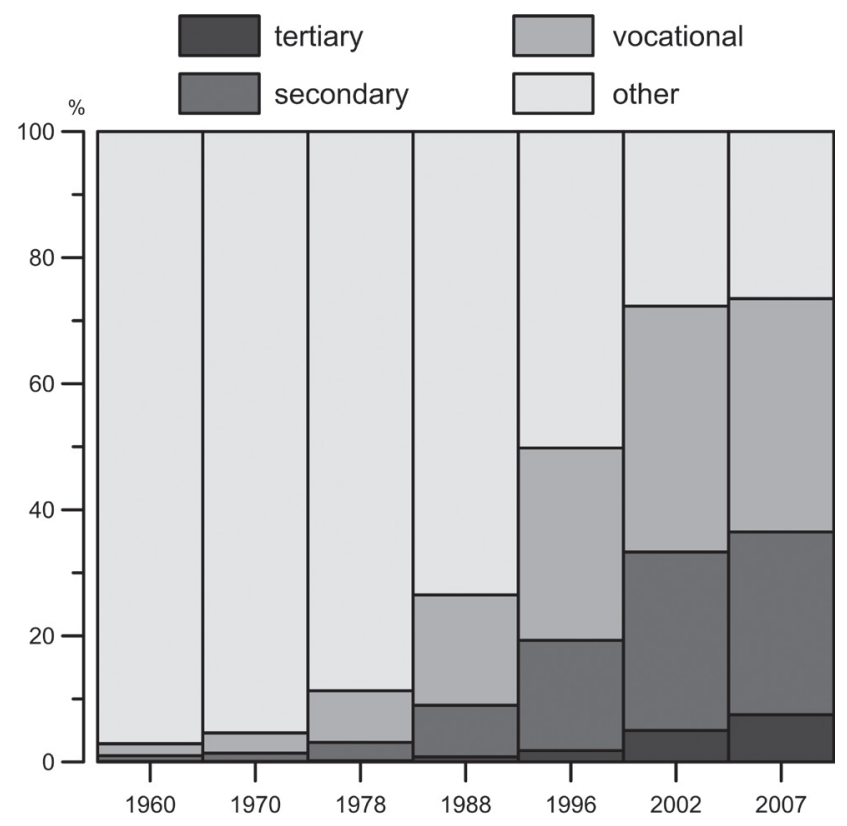

Figure 1. Breakdown of Poland's farming population by level of education 1960-2007.

Source: calculations after Maciejewski (2005) and Central Statistical Office (Farm Structure Survey 2007).

Possible inefficiency of knowledge utilisation is here investigated on three levels, of which (national) brings together national statistics, plus accountancy data collected for Polish farms under the Farm Accountancy Data System (FADN)1. The latter data represent the farms that are core producers of agricultural goods, some 12,000 farms in Poland's case (as set against 750,000 farms overall).

The second level of investigation centres on aggregated statistical data for Poland's gminas (LAU2 level), while the third reflects data for the EU's NUTS3 subregions. In all cases, analysis involves the relationship between indicators describing levels of education of farm managers, the value of output, and incomes from non-agricultural activities. The results at these different levels of investigation provide for methodological triangulation (Yeung 1997).

\section{The farm level of investigation}

The analysis of microeconomic interdependence between the levels of knowledge possessed by farmers and the economic performance of their farms attests to interdependence between the level of education of a farm operator and the economic size of the farm (Tab. 1). Farms operated by a person with a higher level education are characterised by the highest incomes both from farming and from non-agricultural activity. When it comes to farm sizes, a strong relationship

\footnotetext{
1 The Farm Accountancy Data Network (FADN) is a system obliging Member States to apply uniform methodology in the collection of structural and accountancy data on farms. For more information see http://ec.europa.eu/agriculture/rica/.
}

with agricultural education is to be observed - farmers with specialised (agricultural) education operate larger farms than those with the same level of nonagricultural education. On the other hand, a higher level of non-agricultural education is accompanied by relatively higher incomes from activities outside agriculture. However, this is only true as far as average values are concerned. In the case of the top 5\% of incomes (specifying the minimal level of income of the best-performing $5 \%$ of farms), agricultural education prevails over non-agricultural as regards both kinds of activity.

\section{The gmina (local-authority) level of investigation}

The second level of investigation compares advances in farmers' agricultural education with the value of farm market production. The level of productivity of private agriculture was defined as the value of production sold on the market, as expressed in Polish zloty (PLN) per hectare of farm land (Kulikowski 2003).

Recently about $70 \%$ of agricultural production in Poland has been market-orientated. However the level of market production differs between farms, and depends mainly on farm size and production profile. The assessment of the spatial interrelationship between human capital and farm performance seeks to present the geographical aspect to the creation and utilization of agricultural knowledge. Specifically, the identification of territories with a high level of knowledge, favourable from the point of view of social structure, is assumed to be critical where these can be potential 
sources of transfer. In the categorisation that has been carried out, such regions with favourable prospects when it comes to the development of the agricultural function are identified as class I and are seen to account for some $31 \%$ of all gminas. These are mainly located in the voivodships: Wielkopolskie, Kujawsko-Pomorskie, Pomorskie (mostly the Vistula Delta - Zuławy region), the northern part of Łódzkie and the north-western part of Mazowieckie (Fig. 2). These rural areas have prospects of making their development dependent on a market-oriented agricultural function. Standing in contrast are the 42\% of gminas (in class IV) that will have to find other development pathways, because both of the investigated characteristics (endogenous potential expressed in terms of educational level and the productivity of agriculture) were at below-average values. What is interesting is that there are a few gminas assigned to the transitory classes (classes II and III - 17\%). This analysis points to the regionalisation of knowledgetransfer demand as regarding the multifunctional

\section{Level of investigation involving the EU regions}

The third-level analysis conducted for the EU (NUTS2 level) regions reveals a strong correlation $(r=0.69)$ between the level of education of farmers and the economic size of farms (ESU; Fig. 3). Polish regions as compared with EU ones can be characterised by the average level of farmer education and lower economic size of farms. This suggests that human capital in Polish agriculture is less effective than expected in terms of transferring it into farm development. Indeed, quantified model of transformation knowledge at EU level proves the unsatisfactory effectiveness of Polish farmers. According to the regression model Polish farmers could operate farms that are almost 10 times larger than observed (39 ESU instead of 4 ESU). Assuming that the relation between analysed data is non linear, Polish farms are characterised as being five times smaller than expected considering average economic size (average of expected value from

Table 1. Interdependence between the level of education of those running farms and economic performance.

\begin{tabular}{|c|c|c|c|c|c|c|c|c|}
\hline \multirow[t]{2}{*}{ Level of education } & \multicolumn{3}{|c|}{$\begin{array}{l}\text { Farm size in European } \\
\text { Size Unit (ESU) }\end{array}$} & \multicolumn{2}{|c|}{$\begin{array}{l}\text { Incomes from } \\
\text { non-agricultural } \\
\text { activities [PLN] }\end{array}$} & \multicolumn{3}{|c|}{ Farm income [PLN] } \\
\hline & $\bar{a}$ & $\mathrm{Me}$ & top $5 \%$ & $\overline{\mathrm{a}}$ & top $5 \%$ & $\bar{a}$ & $\mathrm{Me}$ & top $5 \%$ \\
\hline Primary & 16.4 & 11.0 & 46.8 & 2,891 & 15,600 & 59,683 & 35,119 & 182,976 \\
\hline $\begin{array}{l}\text { Vocational } \\
\text { non-agricultural }\end{array}$ & 15.6 & 10.7 & 44.1 & 3,657 & 19,250 & 56,749 & 35,052 & 181,133 \\
\hline $\begin{array}{l}\text { Vocational } \\
\text { agricultural }\end{array}$ & 21.9 & 15.8 & 60.6 & 2,474 & 15,600 & 74,172 & 48,441 & 224,716 \\
\hline $\begin{array}{l}\text { Secondary } \\
\text { non-agricultural }\end{array}$ & 18.3 & 10.8 & 56.8 & 5,043 & 25,000 & 77,044 & 38,686 & 245,559 \\
\hline $\begin{array}{l}\text { Secondary } \\
\text { agricultural }\end{array}$ & 24.4 & 16.1 & 66.3 & 3,607 & 20,700 & 90,297 & 54,124 & 281,316 \\
\hline $\begin{array}{l}\text { Tertiary } \\
\text { non-agricultural }\end{array}$ & 20.0 & 10.5 & 74.6 & 8,595 & 15,600 & 88,320 & 38,236 & 390,976 \\
\hline Tertiary agricultural & 30.1 & 14.6 & 94.8 & 8,448 & 39,000 & 130,063 & 54,324 & 438,642 \\
\hline
\end{tabular}

Signatures: $\bar{a}$ - arithmetic mean; Me - median; top 5\% - minimal level of income of the higher-performing 5\% of farms (also maximal level of income of the lower-performing 95\% farms).

Source: calculated on the FADN data for 2006.

development of rural areas. A preponderance of the gminas with poorly-performing agriculture and a low level of knowledge are located in the south-east of Poland. These could be characterised as displaying the greatest demand for rural knowledge, while being poorly endowed where agricultural development is concerned. On the other hand, gminas in the centre of Poland enjoy the greatest potential to specialise further in agricultural production. the model $22 \mathrm{ESU})$. The most important factor, that shape such a results is incompatible agrarian structure in Polish agriculture - average farm area is only 6.6 ha to compare with the 11.5 ha for the whole EU and 20.2 ha for EU-15 countries.

The study shows a high potential for the multifunctional development of Polish rural regions. A higher level of education accompanied by limited economic potential of farms suggests that the economic 


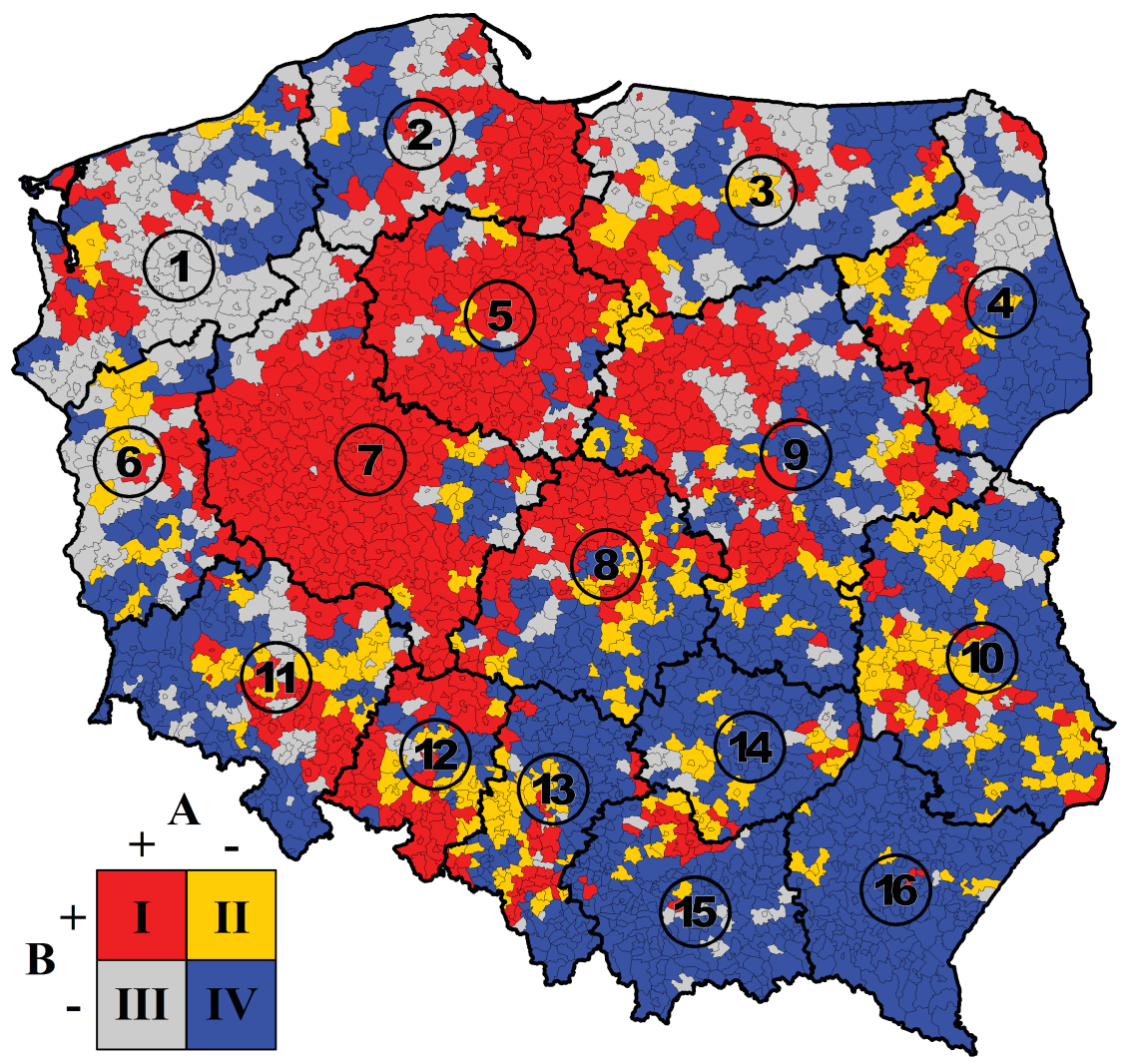

Figure 2. Spatial typology of gminas by level of the agricultural education of farmers (A) and the level of agricultural productivity (B). Identities of the Polish regions (voivodships): 1 - Zachodniopomorskie; 2 - Pomorskie; 3 - Warmińsko-Mazurskie; 4 - Podlaskie; 5 - Kujawsko-Pomorskie; 6 - Lubuskie; 7 - Wielkopolskie; 8 - Łódzkie; 9 - Mazowieckie; 10 - Lubelskie; 11 - Dolnośląskie; 12 - Opolskie; 13 - Śląskie; 14 - Świętokrzyskie; 15 - Małopolskie; 16 - Podkarpackie.

Source: based on the Central Statistical Office data.

situation of rural areas in Poland could be improved significantly were more rural knowledge resources to be utilised outside agriculture. Interdependencies between level of farmer education and farm production and incomes performance characterize the ability of operator to accordingly increase the knowledge and develop farm. This process is strongly related to farmers skill to gather and utilize information from market and readiness to implement innovations.

\section{Modelling the transfer of agriculture knowledge}

The distinct relationship between level of knowledge and the performance of farms presented above calls for an analysis of potential channels by which knowledge transfers on to farms. Account is taken here of the relatively easier transfer of codified - as opposed to tacit - knowledge. Equally, as the codification of knowledge is a basis and a starting point for the acquisition of tacit knowledge, it is assumed that the transfer of knowledge in codified form is proportionally followed by the transfer of tacit knowledge.
Knowledge transfer to rural areas as understood traditionally is concerned with modern agricultural technologies. The induced innovation model of agriculture development in particular links technical changes with agriculture progress assisted by institutional innovation (Hayami \& Ruttan 2006). In this model, progress needs to overcome constraints on the expansion of production arising out of scarcity of supply of production resources. Internally-driven willingness to change is accompanied by interactions between farmers and the world of science responding with new, demanded technologies. The induced innovation model therefore underlines a sensitivity on the part of scientific and public institutions when it comes to the extension of support to agricultural development. Following the new paradigm of rural development (OECD 2006), the induced innovation development model is extended to cover a multisectoral concept for rural areas; hence this article's references to knowledge transfers into both agricultural and non-agricultural activities.

The authors thus propose three models of knowledge transfer that are to be distinguished in line with the path of information flow, i.e. peer-to-peer, global 


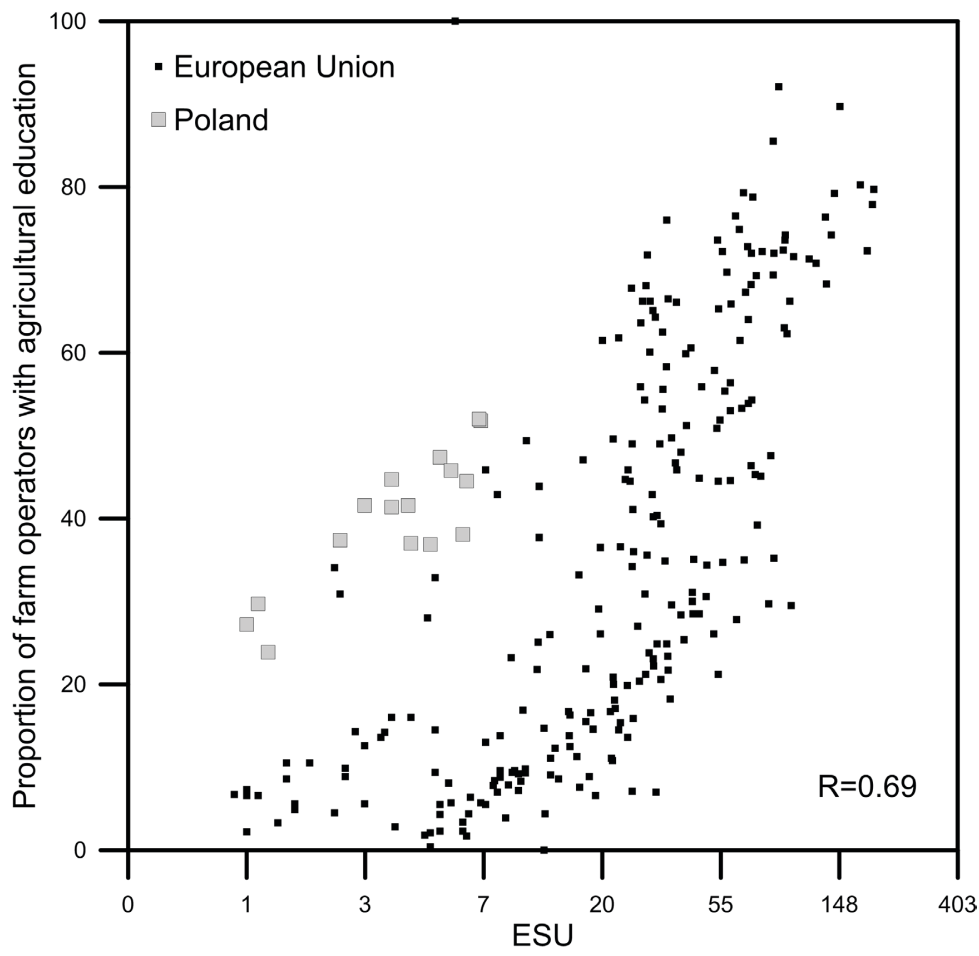

Figure 3. Average economic size of farm in ESU (logarithmic scale) against level of agricultural education of those running farms (in 2005).

Source: calculations based on data of the DG AGRI (2009).

information and direct-from-the-supplier (Floriańczyk 2007). In the peer-to-peer model, a farmer possesses an amount of knowledge received directly from an adviser or another farmer sufficient to implement new technology without further assistance. The model of global information in turn bases itself around general information regarding new technology being supplied by public-access media. In a second step, detailed information is to be collected from an adviser or another farmer. As in the peer-topeer model, the last stage here is the implementation of change. Finally, the direct-from-the-supplier model corresponds to straight knowledge transfer from the provider of it to the farmer. By way of this process, farmers seek possibilities for expansion on their farms through direct contact with a potential supplier of knowledge.

\section{The peer-to-peer model}

Extension services officially responsible for training, advisory and agricultural consultancy were forced to restructure their organisational structures and scope of operations. The conferment of knowledge by the Agricultural Advisory Centre has as its aim the improvement of agricultural performance (the rais- ing of farm competitiveness and incomes), as well as support for rural sustainable development as broadly conceived. In this light, the extension services system in Poland is potentially in line with the new paradigm of rural development, i.a. by covering activities beyond agricultural production. However, the preferences for top-down information flow could distort the balance between formal knowledge that is of external origin. Furthermore, it may become an obstacle to the utilisation of endogenous development factors that are locally specific.

Field research points to a strong correlation between a farmer's educational level and the degree to which advisory services are utilized ${ }^{2}$. 30\% of all respondents declared that they had taken advantage of extension services in farm management. Within that group, the most frequent users of extension services are farmers between 40 and 50 years old. Following them is a group of younger farmers aged 30-40. Farmers of other ages seldom seek support from extension services. As regards level of education, the differences between farmers that have achieved tertiary or secondary levels do not achieve statistical significance. However, farmers in

\footnotetext{
2 Data taken from the Agrinpol Project database for the years 1999-2002 and 2004-2006 (Agrinpol 2006).
} 


\section{Peer-to-peer}

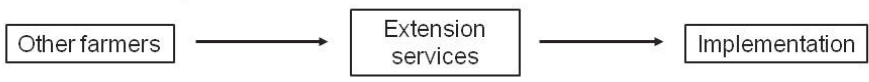

2. Global information

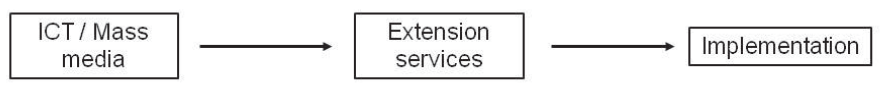

\section{Direct from supplier}

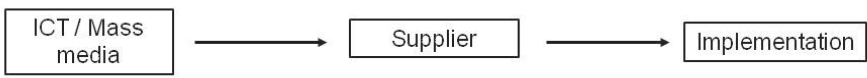

Figure 4. Three models for knowledge transfer in agriculture.

Source: based on Floriańczyk (2007).

these two groups combined were twice as likely as those with primary education only to declare that they had had contacts with extension services (Tab. 2).

Correlation between frequency of extension services utilisation and level of education is to be observed regarding the level of farmer household's standards and perceiving the positive outcomes of accession to the EU (Bański 2005). Within the investigated group about $30 \%$ of farmers declare frequent collaboration with extension services. On the other hand the share of non-farmer rural population that contacts with extension services does not exceed $10 \%$. That reflects both the rural population opinion of agricultural speciality of extension services and improper model of knowledge transfer to rural population.

\section{Global information model}

The global information model of knowledge transfer to agriculture can be recognized as the one potentially offering the most promise when it comes to the application of modern communications technologies. Information on new technologies of production and management, as well examples of their application in agriculture can be disseminated with the aid of television, specialized newspapers and the Internet, these all guaranteeing wide-ranging distribution. The Internet in particular has a potential to provide specific in- formation for the farm manager that can be verified with the support of extension services, at the second stage of knowledge transfer. Positive assessment of the information results in the application of the new production technology or management. The global information model for knowledge transfer with the use of the Internet, after Warren $(2002,2004)$, tends to be used intensively on larger farms. Farms with greater resources make major use of computers in management, and utilize the Internet to gather information, not only on market development, but also on new technologies of production. These findings are in sharp contrast with similar investigations carried out in Poland's Małopolskie voivodship. The results of research done by Cupiał and Szelag-Sikora (2008) point to only marginal use of the Internet on farms, be these small or large. This phenomenon can be accounted for by limited confidence in the quality of information available through such open-access resources as the Internet.

However, the higher the level of educational attainment of the farm operator, the more positive the attitude when it comes to acceptance of the Internet as a source of information. Further findings of the same researchers also suggest a greater willingness of larger farms to base their technological development on various different sources of knowledge. Cross-examination here confirms the value of information and the competency of its sources. This creates an environment in

Table 2. Farmers' collaboration with extension services.

\begin{tabular}{|l|c|c|}
\hline Educational level & Collaboration with extension services & Population (statistic sample) \\
\hline Tertiary & $38[\%]$ & 29 \\
Secondary & $36[\%]$ & 290 \\
Vocational & $30[\%]$ & 443 \\
Primary & $18[\%]$ & 169 \\
Total & $30[\%]$ & 931 \\
\hline
\end{tabular}

Source: calculations based on Bański (2005). 
which broad use may be made of the Internet in rural areas of Poland, but still shows the gap between ICT utilization in farming as characterizing agriculture in the East and West. Limited professional utilization of the Internet on Polish farms is accompanied by a relatively higher level of utilization of computers for other purposes. According to Czapiński and Panek (2009) and GUS data (2008), some 30\% of farmers use computers, while - depending on the source of data - 25-28\% utilize the Internet. This can be considered a significant improvement, since in 2005 only $10 \%$ of farmers declared that they utilized the Internet. On the other hand, only the socio-economic group comprising the retired and pensioners were less familiar with the utilization of this technology. Empirical evidence from both aforementioned investigations reveals significant differences between rural and urban areas when it comes to role the Internet plays in the global information model for knowledge transfer. The less-favourable position of the rural population is to be explained by differences in accessibility, and in ability to use online resources. Where the effectiveness of the global information model is concerned, rural infrastructure and the human capital of the rural population are deemed to be critical factors (Fig. 4).

\section{The direct-from-the-supplier model}

The third model for knowledge transfer - direct-from-the-supplier - omits the stage of information gathering entailing an advisor or other farmers. General information from public sources stimulates direct contact between a farmer and the supplier of technology, with a view to the latter being implemented. In this model, the majority of farms are already advanced technologically, and operate on a scale relatively large enough to suggest a potential to become a direct partner for a supplier of technology. This model can be characterised as exclusive and reserved for the high-knowledge farm operator able to recognise the opportunities offered by new technology, and to consider risk-taking over the investment on the basis of own observations. A further critical point in the direct-from-the-supplier model is a capacity on the part of those producing technology to attract their potential customers and provide basic information for them. The investigation conducted on farms that decided to take up new technology showed that $32 \%$ of them made direct contact with the supplier of the technology with a view to obtaining $i t^{3}$. This relatively large share should be set against the superior position of the farms investigated. However, the results support the hypothesis that there is high endogenous potential to develop their business on the part of farms with fuller knowledge. At the same time, the same group of respondents complained about the quality of extension services - 79\% mentioning a knowledge gap, and a lack of informa-

\footnotetext{
3 Data taken from the Agrinpol Project database for the years 1999-2002 and 2004-2006 (Agrinpol 2006).
}

tion regarding the possibilities for capital support to be obtained, and 56\% referring to marketing skills. These findings support a conclusion regarding limited levels of specialization of extension services, as well as unsatisfactory identification of top-performance farmers demand, in the sense of the induced innovation model of agricultural development.

The direct-from-the-supplier model for knowledge transfer can be characterized as dependent on public institutions, such as extension services, to only a limited degree. It can thus be regarded as most effective from the public finance point of view. In contrast, the extension services are directly involved in the knowledge transfer taking place by virtue of the peer-topeer and global information models, these two being preferred by the small and medium-sized farms that constitute the majority. This points to increased efficiency of the public system with a growing number of farms. The generally limited educational potential of farming populations indicates that the direct from the suppliers model of knowledge transfer only applies to a narrow population. On the other hand, the models with advisory participation are seen to be of greater importance.

\section{Conclusions}

The classical problem of the transfer of knowledge into agriculture has become more complex in recent times. This is related with the general process by which knowledge is assuming ever greater importance where economic development is concerned. A changing economic environment increases the need for specialisation and the use of up-to-date technology. In respect of agriculture, the implementation of modern technological solutions used to be further complicated by the marked degree to which traditional agriculture depends on local (tacit) knowledge, and the distances separating villages from knowledge centres. Simultaneously, the capacity of farming activity to provide satisfactory income for an agricultural population has declined in relative terms, this reflecting the faster development of other sectors of the economy. New paradigms of rural development underline the multifunctionality of rural areas, indicating possibilities for rural development by way of the fuller utilisation of local resources in activities beyond agriculture. Implementation of the concept of multifunctional rural development is linked with the evolution of farmers into managers. This process creates a demand for knowledge of the new dimensions away from agriculture.

Among the existing theories, it is the induced innovation model of agricultural growth that is capable of addressing new rural challenges. This recognises the issue of local knowledge and defines the environment necessary for effective institutional support of the development process. Institutions as extension services are expected to monitor local demand for knowledge, and to make an effort to de- 
liver it. New information and communications technologies have the potential to facilitate the process of knowledge diffusion. However, relatively poor access and (lack of) skills among the rural population are major obstacles to these technologies being utilised.

The matter of knowledge transfer, as interrelated with the multifunctional development of rural areas concept, is of great importance in agriculture dominated by small family farms. Limited possibilities for agricultural output to increase entail development being directed towards the non-agriculture utilisation of rural resources. Analysis of the interactions between level of knowledge and the performance of Polish farms attests to the dynamic improvement in the educational attainments of the rural population over the last few years. Farm operators with a higher level of agricultural education tend to run larger farms with higher incomes, whether these derive directly from farming or from non-agricultural activity. In turn, the analysis of data at gmina level clearly points to the south-east as characterised by a low level of knowledge and attendant farm performances that demand institutional support for the transfer of knowledge. On the other hand, there is also the central and western part of Poland, with its highly-educated farmers and effectively performing farms that do enjoy the potential for further development. The relationship between operators' levels of education and farm size at regional level still suggest more limited utilisation of human capital in Polish rural areas than is the case in most other EU countries. Such ineffectiveness calls for intensified implementation of the multifunctional rural development concept. This to be connected directly with more effective application of rural human capital where activity outside agriculture is concerned.

Extension services are traditionally recognised as a main channel for the provision of agricultural knowledge. However, the multifunctional rural development concept requires a reorientation of their services portfolio, and regional specialisation. Among the investigated models of knowledge transfer to agriculture the peer-to-peer and global information models incorporate extension services. Peer-to-peer is recognised as being sensitive to the tacit kind of knowledge. Under this model, extension services respond to local-community needs with a formal kind of knowledge. Where the effective transfer of knowledge in this model is concerned, the target group comprises farms of low profitability and low levels of educational attainment on the part of operators. The relatively poor communication achieved by this group of farmers can be explained under the induced innovation rural development model. Traditional preferences for extension services to follow the 'top-down' central planning formula do not respond to local demand, the result being limited interest in using, and in receiving assessments from, rural population extension services. South-eastern Poland is dominated by poor farms, and hence designated for the application of peer-to-peer knowledge transfer. However, in this case a broadening of extension-service activities is critical, for the rare contacts between the non-farmer rural population and extension services indicate that a reorientation of their activities towards the multifunctional development of rural areas is warranted.

The global information model appears to be of the most limited effectiveness when it comes to the transfer of knowledge to rural areas. In this model, only general information can be transferred, while modern information and communications technologies are either inaccessible to farmers or else an unreliable source of information. However, with growing educational attainments on the part of the rural population, this might became an effective way of initiating the process of formal knowledge transfer.

The most effective knowledge transfer using the direct-from-the-supplier model is more limiting in agriculture due to a high initial knowledge level obstacle. This leaves it attractive to only a narrow group of farmers who possess the skills to cooperate directly with external formal-knowledge resources. Within this group of farmers, extension services are of minor importance, since they are incapable of providing the most up-todate knowledge. In this case, extension services could rather focus on providing information on potential demand to technology suppliers, rather than farmers.

This research outcomes should be used directly in the programming of policies aiming at improvement of human capital and rural economy. It allows for precise formulation of policy instruments in order to increase its efficiency and finally insure sustainability of rural development. It should be emphasised that knowledge in any dimension (spatial and microeconomic) is crucial in development of rural economy. But, knowledge that is practically utilised is a characteristic of 'a few' farmers.

\section{Acknowledgements}

Publication prepared within the project 2011/01/D/ HS4/03295 "Models of knowledge transfer in agriculture and its influence on agricultural productivity - spatial analysis" financed by the Polish National Science Centre and carried out in the Institute of Geography and Spatial Organization, Polish Academy of Sciences in the years 2011-2015. 


\section{References}

AgrinPOL, 2006. Przedsiębiorczość wiejska. Baza danych www. agrinpol.pl. Warszawa: Fundacja Fundusz Współpracy, 44 pp. http://www.agrinpol.pl [1 April 2012]

BAŃSKI J., 2005. Przestrzenny wymiar współczesnych procesów na wsi. Studia Obszarów Wiejskich, vol. 9, Warszawa: Instytut Geografii i Przestrzennego Zagospodarowania PAN, Polskie Towarzystwo Geograficzne, $136 \mathrm{pp}$.

BassaninI A., ScARPETTA S., 2002. Does human capital matter for growth in OECD countries? A pooled meangroup approach. Economic Letters, vol. 74, iss. 3, pp. 399-405.

Bathelt H., Malmberg A., Maskell P., 2004. Clusters and knowledge: Local buzz, global pipelines and the process of knowledge creation. Progress in Human Geography, vol. 28, no. 1, pp. 31-56.

BECKER G.S., 1962. Investment in human capital: A theoretical analysis. Journal of Political Economy, vol. 70, no. 5, part 2, pp. 9-49.

Boschma R.A., 2005. Proximity and innovation: A critical assessment. Regional Studies, vol. 39, iss. 1, pp. 61-74.

Boschma R.A., LAMBOOY J.G., 1999. Evolutionary economics and economic geography. Journal of Evolutionary Economics, vol. 9, iss. 4, pp. 411-429.

Brunello G., Coml S., 2004. Education and earnings growth: Evidence from 11 European countries. Economics of Education Review, vol. 23, iss. 1, pp. 75-83.

Chatterul M., 1998. Tertiary education and economic growth. Regional Studies, vol. 32, iss. 4, pp. 349-354.

Clark J.B., 1907. Concerning the nature of capital: A reply. Quarterly Journal of Economics, vol. 21, no. 3, pp. 351-370.

Cupiat M., Szeląg-Sikora A., 2008. Wpływ powierzchni użytków rolnych oraz wykształcenia właściciela na sposoby pozyskania informacji w wybranych gospodarstwach Małopolski. Inżynieria Rolnicza, vol. 12, no. 4 (102), pp. 175-180.

CZAPIEWSKI K., JANC K., 2008. Zróżnicowanie przestrzenne poziomu wykształcenia ludności wiejskiej i rolniczej. Czasopismo Geograficzne, vol. 79, iss. 4, pp. 333-354.

CZAPIŃski J., PANEK T. (eds.), 2009. Diagnoza społeczna 2009. Warunki i jakość życia Polaków. Warszawa: Rada Monitoringu Społecznego, Wyższa Szkoła Finansów i Zarzadzania w Warszawie, http://www.diagnoza.com/ pliki/raporty/Diagnoza_raport_2009.pdf [12 February 2010].

De la Fuente Á., Ciccone A., 2002. Human capital in a global and knowledge-based economy. Paris: European Commission. Directorate-General for Employment and Social Affairs [typescript].

DG AGRI, 2009. Rural development in the European Union. Statistical and economic information, Report 2009. s.l.: European Union. Directorate-General for Agriculture and Rural Development, 411 pp., http://ec.europa.eu/agriculture/agrista/rurdev2009/RD_Report_2009.pdf [1 April 2012].

Durand G., Van Huylenbroeck G., 2003. Multifunctionality and rural development: A general framework. [in:] G. Durand, G. Van Huylenbroeck (eds.), Multifunctional agriculture: A new paradigm for European agriculture and rural development. Aldershot: Ashgate, pp. 1-16.
Eicher C.K., StaAtZ J.M. (eds.), 1998. International agricultural development. Baltimore: The Johns Hopkins University Press, 3rd edn., 615 pp.

European Commission, 2010. Europe 2020. A European strategy for smart, sustainable and inclusive growth. Brussels: European Commission, 37 pp. http://ec.europa.eu/ research/era/docs/en/investing-in-research-europeancommission-europe-2020-2010.pdf [1 April 2012]

FLORIAŃCZYK Z., 2007. Rural technology transfer in transition economies in Poland. D12-3 Fourth 6-monthly report. CEEC AGRI POLICY: Agro economic policy analysis of the new member state, the candidate states and the countries of the western Balkan. Internet: Agripolicy.net, 17 pp. http:// www.euroqualityfiles.net/cecap/ Report 4/Section 2 country report/CEECAP report 4 section 2 POLAND.pdf [1 April 2012].

Floriańczyk Z., CZAPIEWSKI K., StaWiCKa E., 2009. New paradigm of rural development - New challenges for extension services. [in:] J. Neuwirth, K. Wagner (eds.), Multifunctional territories: Importance of rural areas beyond food production, Vienna: Federal Institute of Agricultural Economics, pp. 275-284.

FLORIDA R., 2004. The Rise of the creative class: And how it's transforming work, leisure, community and everyday life. New York: Basic Books, 404 pp.

Fox W.F., PORCA S., 2007. Investing in rural infrastructure. International Regional Science Review, vol. 24, no. 1, pp. 103-133.

GerTLER M.S., 2003. Tacit knowledge and the economic geography of context, or the undefinable tacitness of being (there). Journal of Economic Geography, vol. 3, no. 1, pp. 75-99.

GÖSSLING T., RUTTEN R., 2007. Innovation in regions. European Planning Studies, vol. 15 , no. 2, pp. 253-270.

GRIMES S., 2000. Rural areas in the information society. Diminishing distance or increasing learning capacity. Journal of Rural Studies, vol. 16, no. 1, pp. 13-21.

GUILE D., 2001. Education and the economy. Rethinking the question of learning for the 'knowledge' era. Futures, vol. 33, no. 5, pp. 469-482.

GUS, 2008. Wykorzystanie technologii informacyjno-telekomunikacyjnych w przedsiębiorstwach, gospodarstwach domowych i przez osoby prywatne w 2008 r. Wyniki Badań GUS. Notatka informacyjna, Warszawa: Główny Urząd Statystyczny. Departament Przemysłu, 13 pp. http://www.stat.gov.pl/cps/ rde/xbcr/gus/PUBL_NTS_wykorzystanie_tech_infor-telekom_2008.pdf [1 May 2012].

HaYAMI Y., RUTTAN V., 1985. Agricultural development: An international perspective. Baltimore: The Johns Hopkins Press, 2nd edn., 367 pp.

HILL B., CoOK E., 1996. Eurostat's statistics on the Total Income of Agricultural Households (TIAH statistics): main results and their interpretation. [in:] B. Hill (ed.), Income statistics for agricultural household sector. Luxembourg: Office for Official Publications of the European Communities, pp. 104-116.

HILPERT U., 2006. Knowledge in the region: Development based on tradition, culture and change. European Planning Studies, vol. 14 , no. 5, pp. 581-599.

HOWELlS J.R., 2002. Tacit knowledge, innovation and economic geography. Urban Studies, vol. 39, no. 5-6, pp. 871-884. 
Johnson T.G., 2001. The rural economy in a new century. International Regional Science Review, vol. 24, iss. 1, pp. 21-37.

KLEPACKI B., 2005. Wykształcenie jako czynnik różnicujacy zasoby, organizację i wyniki ekonomiczne gospodarstw rolniczych. Roczniki Naukowe SERiA, vol. 7 , no. 1, pp. 124-128.

KULIKOWSKI R., 2003. Syntetyczne metody badań produktywności i towarowości rolnictwa. Zastosowania w badaniach geograficznych w Polsce. Prace Geograficzne, no. 187, Warszawa: Instytut Geografii i Przestrzennego Zagospodarowania PAN, $148 \mathrm{pp}$.

LAgendiJk A., LoRentzen A., 2007. Proximity, knowledge and innovation in peripheral regions. On the intersection between geographical and organizational proximity. European Planning Studies, vol. 15, no. 4, pp. 457-466.

LLOYD-ELLIS H., ROBERTS J. 2002. Twin engines of growth: Skills and technology as equal partners in balanced growth. Journal of Economic Growth, vol. 7, no. 2, pp. 87-115.

LUCAS R.E., 1988. On the mechanics of economic development. Journal of Monetary Economics, vol. 22, no. 1, pp. 3-42.

LUNDVALL B. $\AA$., 1996. The social dimension of the learning economy. DRUID Working Paper, no. 96-1, Aalborg: Department of Business Studies. Aalborg University, 29 pp., http://www3.druid.dk/wp/19960001.pdf [1 April 2012].

MACIEJEWSKI K., 2005. Wykształcenie ludności zwiqzanej z rolnictwem w Polsce. [in:] M. Adamowicz (ed.), Zarzqdzanie wiedza w agrobiznesie w warunkach polskiego członkostwa w Unii Europejskiej, Prace Naukowe. Szkoła Główna Gospodarstwa Wiejskiego. Wydział Ekonomiczno-Rolniczy. Katedra Polityki Agrarnej i Marketingu, no. 35, Warszawa: Wydawnictwo SGGW, pp. 125-133.

MALECKI E.J., 2003. Digital development in rural areas: Potentials and pitfalls. Journal of Rural Studies, vol. 19, no. 2, pp. 201-214.

McCormick K., 2002. Veblen and the new growth theory: Community as the source of capital's productivity. Review of Social Economy, vol. 60, no. 2, pp. 263-277.

OECD, 2006. The new rural paradigm: Policies and governance. 101 pp. http://www.oecd.org/gov/thenewruralparadigmpoliciesandgovernance.htm [1 April 2012]

Poncet P., Ripert B., 2007. Fractured space: A geographical reflection on the digital divide. GeoJournal, vol. 68, no. 1, pp. 19-29.

Romer P.M., 1990. Endogenous technological change. Journal of Political Economy, vol. 98, no. 5, pp. 71-102.

ROMER P.M., 1994. The origins of endogenous growth. Journal of Economic Perspectives, vol. 8, no. 1, pp. 3-22.

SCHUlTZ T.W., 1961. Investment in human capital. American Economic Review, vol. 51, pp. 1-17.
Solow R.M., 1956. A contribution to the theory of economic growth. The Quarterly Journal of Economics, vol. 70, no. 1, pp. 65-94.

Storper M., Venables A.J., 2004. Buzz: Face-to-face contact and the urban economy. Journal of Economic Geo-graphy, vol. 4, no. 4, pp. 351-370.

SWAGEMAKERS P., 2003. Novelty production: new directions for the activities and role of farming. [in:] G. Durand, G. Van Huylenbroeck (eds.), Multifunctional agriculture: A new paradigm for European agriculture and rural development, Aldershot: Ashgate, pp. 189-207.

SzeląG-Sikora A., Cupiat M., 2008. Liczba źródet informacji rolniczej a poziom wyposazienia gospodarstw rolnych $w$ techniczne środki. Inżynieria Rolnicza, vol. 12, no. 6 (104), pp. 187-194.

TÖRNQVIST G., 2004. Creativity in time and space. Geografiska Annaler. Series B. Human Geography, vol. 86, no. 4, pp. 227-244.

VEBLEN T., 1908a. On the nature of capital. The productivity of capital goods. Quarterly Journal of Economics, vol. 22, no. 4, pp. 517-542.

VEBLEN T., 1908b. On the nature of capital: Investment, intangible assets, and the pecuniary magnate. Quarterly Journal of Economics, vol. 23, no. 1, pp. 104-136.

WARREN M., 2002. Adoption of ICT in agricultural management in the United Kingdom: The intra-rural digital divide. Agricultural Economics, vol. 48, no. 1, pp. 1-8.

WARREN M., 2004. Farmers online: Drivers and impediments in adoption of the Internet in UK agricultural businesses. Journal of Small Business and Enterprise Development, vol. 11, no. 3, pp. 371-381.

Warren M., 2007. The digital vicious cycle: Links between social disadvantage and digital exclusion in rural areas. Telecommunications Policy, vol. 31, no. 6-7, pp. 374-388.

Whitacre B.E., Mills B.F., 2007. Infrastructure and the rural-urban divide in high-speed residential Internet access. International Regional Science Review, vol. 30, no. 3, pp. 249-273.

WILCOX W.W., 1943. Capital in Agriculture. Quarterly Journal of Economics, vol. 58, iss. 1, pp. 49-64.

YEUNG H.W.C., 1997. Critical realism and realist research in human geography: a method or a philosophy in search of a method? Progress in Human Geography, vol. 21, no. 1, pp. 51-74. 